\title{
VARIABILITY OF DYNAMIC CORRELATION - THE EVIDENCE OF SECTOR-SPECIFIC SHOCKS IN V4 COUNTRIES
}

\author{
Jitka Poměnková, Svatopluk Kapounek, Roman Maršálek*
}

\begin{abstract}
:
We focus on changes in dynamic correlation during the recent financial crisis. The results show different responses to this symmetric shock in V4 countries. We discuss possible specialization if the dynamic correlation increases only at certain of the frequencies. Especially, in case of the Czech Republic where the variability of dynamic correlation in business cycle frequencies increased in relation to the euro area, whereas decreased in relation to Germany. Consequently, we point out to the limitations of a correlation and concordance index as common indicators of business cycle synchronization in time domain.
\end{abstract}

Keywords: OCA theory, synchronization, business cycle, frequency domain, concordance index, real convergence.

JEL Classification: E32, F15, C14

\section{Introduction}

One of the commitments associated with accessing the European Union (EU) includes adopting euro and giving up the monetary policy autonomy. This act is conditioned by satisfying the Maastricht nominal convergence criteria. Nevertheless, the costs and benefits are associated with fulfilling the real convergence criteria based on the Optimum Currency Area (OCA) theory. Despite the theory, the euro area member countries did not evidently fulfill the Optimum Currency Area (OCA) criteria, possibly with the exception of a small DM-area which had been relatively integrated even before the euro. Nevertheless, the question is whether the OCA theory provides an appropriate framework for the creation of the monetary union.

* Jitka Poměnková, Roman Maršálek, Department of Radio Electronics (DREL), Brno University of Technology, Technická 12,CZ - 61600 Brno (pomenkaj@feec.vutbr.cz, marsaler@feec.vutbr.cz); Svatopluk Kapounek, Department of Finance, Faculty of Business and Economics, Mendel University in Brno, Zemědělská 1, CZ - 61300 Brno (kapounek@mendelu.cz ). The authors thank to Jarko Fidrmuc, Jan Fidrmuc, Hubert Gabrisch and Karsten Staehr for useful comments and suggestions. We have benefited from the presentations at the $5^{\text {th }}$ FBE Mendel International Conference (Brno, November 2011) and the $12^{\text {th }}$ EACES International Conference (Paisley, September 2012).

The research described in the paper was supported by the Czech Science Foundation via Grant No. P402/11/0570 by Jean Monnet Multilateral Research Group Grant No. 530069-LLP-1-2012-1CZ-AJM-RE and by the Project CZ.1.07/2.3.00/20.0007 WICOMT of the Operational Programme - Education for Competitiveness and Internal Grant Agency under project No. FEKT-S-14-2177 (PEKOS). It was performed in the laboratories supported by the SIX Project; the Registration Number CZ.1.05/2.1.00/03.0072, the Operational Programme - Research and Development for Innovation. 
The literature has employed various econometric methods to estimate the degree of real convergence. We follow the assumption that the fulfillment of the real convergence criteria in a broadly defined sense results in highly correlated business cycles (Artis, Zhang, 1999; Fatás, 1997). However, there are several widely discussed outstanding issues stemming from the business cycle correlation analyses. (1) The OCA theory does not provide a clear definition of sufficient degree of business cycle synchronization, (2) different measures of business cycles often provide different results (Fidrmuc, Korhonen, 2006) and (3) the assessment of the past developments has no value for the future developments (Lucas, 1976).

Our contribution is in a detailed look into the structure of time series and separate analysis of individual frequencies. We apply the frequency domain approach and focus on dynamic correlation shape. We argue that high correlation in full range of frequencies is not evidence of economic cycle synchronization if this correlation is changing at different frequencies. We assume that the variability of dynamic correlation at different frequencies indicates sector-specific shocks which limit real convergence.

The frequency domain approach was applied by Croux et al. (2001), Messina et al. (2009), Fidrmuc and Korhonen (2010) or Fidrmuc, J. et al. (2012), but the recent empirical studies applied dynamic correlation at full range of frequencies or at selected range of frequencies (mostly at business cycle frequencies. i.e. from 8 to 32 quarters).

The purpose of this paper is twofold: (1) to identify changes in business cycle synchronization of V4 countries with the euro area during the recent financial crisis and (2) to assess the variability of estimated dynamic correlation at different range of frequencies. The results are discussed in the context of OCA endogeneity hypothesis and compared with the indicators of regional specialization - the Herfindahl-Hirschman Index, the Krugman Dissimilarity Index and the Lilien Index.

\section{Theoretical Background}

The traditional version of the optimum currency area (OCA) theory originates from the debates about fixed versus flexible exchange rates, treating a common currency as the extreme case of a fixed exchange rate. Mundell (1961) pioneered with a simple idea that flexible exchange rates are based on regional currencies, not on national currencies if the macroeconomic shocks affect these regions differently. Inspired by Keynes and his price and wage rigidities assumptions, Mundell argues that if there is a high degree of labour mobility within a region, then the member states should have a fixed exchange rate regime and a flexible exchange rate against the rest of the world. The modern reconsideration of the OCA theory generally considers three market-based adjustment mechanisms to asymmetric shocks within the currency union: (1) wage and price flexibility, (2) mobility of labour and (3) mobility of capital. It is, however, widely discussed and generally agreed that increasing labour and capital mobility can lead to regional concentration and industrial specialization (Krugman, 1992, 1993; Eichengreen, 1992; Bertola, 1993; 
Rauch, Weinhold, 1999). The regional concentration within the currency union is, however, defined by activities, not geographically or politically. Horváth and Komárek (2002) argued that Krugman's view implicitly assumes that the regional concentration of industry will not cross the borders of the countries within the currency union.

The key problem is that the wage and price settings appropriately reflect different situations of specific sectors or firms and overall market conditions. Whereas the currency devaluation affects prices of all exported and imported goods and could increase competitiveness of the country in short term, the wage and price adjustment mechanisms affect sectors and firms heterogeneously.

Carlsson and Nordstrom Skans (2012) or Druant et al. (2009) showed a heterogeneous degree of the price rigidity across the sectors. Druant et al. $(2009$, p. 4) identified that the degree of rigidity "depends strongly on economic features, such as the intensity of competition, the exposure to foreign markets and the share of labour costs in total cost." Assume that the differences across firms, sectors and countries concern the frequency and timing of wage and price changes and their relationship. Frequencies of adjustment to shocks, therefore, differ across the sectors and imply asymmetric effects of shocks within individual countries.

This heterogeneity appears also in the case of symmetric shock, such as decline in economic activity caused by financial crisis. Assume highly specialized countries and heterogeneous sectoral structure within the currency area where symmetric shocks increase unemployment. In that case, highly correlated business cycles in time domain indicate synchronization but efficiency of the common monetary policy will be limited by heterogeneous adjustment to the changes of the common central bank's interest rates. The limitation increases with industrial specialization when symmetric macroeconomic shocks appear to be sector-specific shocks.

\section{Methods}

In order to quantify the co-movements in time series, we use the concept of the dynamic correlation according to Croux et al. (2001). The dynamic correlation measures the similarity of the frequency components of two time series $y$ and $z$ and can be defined as:

$$
\rho_{y z}(\omega)=\frac{C_{y z}(\omega)}{\sqrt{S_{z}(\omega) S_{y}(\omega)}},
$$

where $C y z$ is a co-spectrum (the real part of the cross-spectrum) and $S y, S z$ are the individual spectra of time series $y$ and $z$ for frequencies $\omega$. The dynamic correlation values can lie in the interval from -1 to +1 . Integrating the formula in the frequency band from $\omega_{1}$ to $\omega_{2}$ a dynamic correlation coefficient arises: 


$$
\rho_{y z}\left(\omega_{1}, \omega_{2}\right)=\frac{\int_{\omega_{1}}^{\omega_{2}} C_{y z}(\omega) d \omega}{\sqrt{\int_{\omega_{1}}^{\omega_{2}} S_{z}(\omega) d \omega \int_{\omega_{1}}^{\omega_{2}} S_{y}(\omega) d \omega}},
$$

which evaluates the common behaviour of two time series in the given band of frequencies, e.g. in the business cycle frequencies. For $\omega_{1}=0, \omega_{2}=\pi$ the integration is done over the whole defined frequency range and thus the dynamic correlation coefficient corresponds to the classical correlation coefficient (Bátorova et al., 2013).

The industrial specialization of the countries is measured on the basis of the gross value added and the number of employed population. The first popular figure in most empirical studies on this topic is the Herfindahl-Hirschman Index (Herfindahl, 1950; Hirschman, 1964) for specialization, defined as:

$$
H_{i}^{S}=\sum_{j=1}^{m}\left(\frac{g_{i j}}{g_{i}}\right)^{2}, j=1, \ldots, m, i=1, \ldots, n,
$$

where $g_{i j}$ is gross value added in branch $j$ and country $i$ and $g_{i}$ is total gross value added in country $i$. The Krugman Dissimilarity Index (Krugman, 1991) used for measuring specialization is defined as:

$$
K_{i}^{S}=\sum_{j=1}^{m}\left|\frac{g_{i j}}{g_{i}}-\frac{g_{j}}{g}\right|, j=1, \ldots, m, i=1, \ldots, n,
$$

where $g$ represents the total gross value added of the whole region. The third indicator of specialization is the Lilien Index (Lilien, 1982). This index reflects the speed of the sectoral employment reallocation in the economy:

$$
L_{i}^{S}=\sqrt{\sum_{j=1}^{m} \frac{e_{i j}}{e_{i}}\left(\Delta \log e_{i j}-\Delta \log e_{i}\right)^{2}}, j=1, \ldots, m, i=1, \ldots, n,
$$

where $e_{i j}$ represents employment (persons) in the sector $j$ and the country $i$ and $\mathrm{e}_{i}$ is the total employment (persons) in the country $i$.

The concordance index measures the degree of synchronization of cycles via fractions of time when the cycles are in the same phase (Harding and Pagan, 2006). The resultant value lies between 0 and 1 and identifies the proportion of the time when two time series are in the same phase of business cycle. The corresponding formula for its calculation takes the form

$$
I_{i j}=\frac{1}{n}\left\{\sum_{t=1}^{n} S_{i t} S_{j t}+\sum_{i=1}^{n}\left(1-S_{i t}\right)\left(1-S_{j t}\right)\right\},
$$


where $S_{i t}=1\left(S_{j t}=1\right), t=1, \ldots, n$ denotes that the country $i(j$ respectively $)$ is in the time $t$ in recession, $S_{i t}=0\left(S_{j t}=0\right)$ denotes that the country $i(j$ respectively) is in the time $t$ in expansion. You can see Harding and Pagan (2006) for a detailed description.

In order to identify the turning points which help to distinguish business cycle phases we apply the Bry-Boschan procedure. The idea of Bry-Boschan algorithm is to present different levels of smoothing with the aim to localize surroundings of potential turning points which are consequently specified with the help of input time series. In the first step, the Bry-Boschan algorithm identifies the major cyclical movements. Consequently, the algorithm determines the surroundings of maxima and minima. At the end the algorithm proceeds to narrowing the search of turning points leading to the specification of the turning moment. This algorithm takes into account the individual nature of time series. A more detailed description of this procedure is provided in Bry and Boschan (1971).

\section{Data Description}

We use seasonally adjusted quarterly values of gross domestic product at prices of the year 2000. We analyze the economic cycles in the euro area (EA12), the Czech Republic (CZ), Hungary (HU), Poland (PL) and Slovakia (SK) in the period 1997/Q1-2012/Q3. Germany (DE) in the same period is included due to the foreign trade linkage and geographical proximity which can allow the concentration of cross-industry. The source of the data is Eurostat (Eurostat, 2012a).

In order to isolate the business cycle frequencies (Figure 1) we use the Hamming Window filter (HW) proposed for the short time series by Iacobucci and Noullez (2005). Prior to the application of the HW filter, we remove the trend by using the high-pass HodrickPrescott filter (Hodrick, Prescott, 1980).

Regional specialization is calculated by gross value added at prices of the year 2000 and employed persons at the NACE Rev.2 aggregation level in the period 2000/Q1-2012/Q1 (2004/Q2-2012/Q1 in case of employment in Poland). In terms of specialization, the whole region is represented by the European Union (EU27). All datasets were gathered from the national accounts aggregates and labour market statistics provided by Eurostat (Eurostat, 2012b). 
Figure 1

Growth Business Cycles of Selected Countries
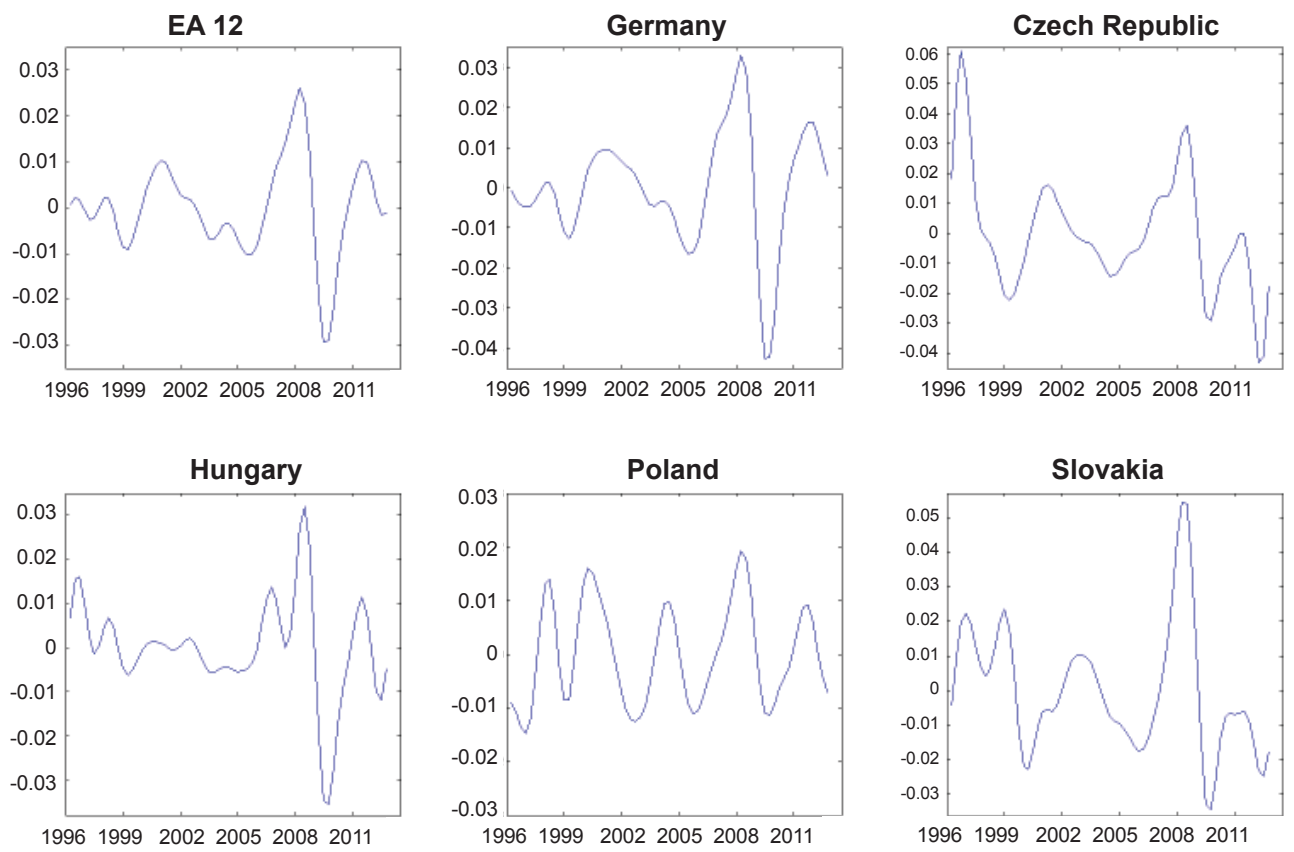

\section{Basic Results}

After business cycle identification, we proceed with measuring the co-movement via dynamic correlation. We calculate the dynamic correlation and its volatility (with respect to the frequency) in business cycle frequencies and also in full range of frequencies. The value of dynamic correlation in full range of frequencies were calculated according to the formula (2) with the integration limits $\omega_{1}=0, \omega_{2}=\pi$. We perform all calculation in four periods, i.e. 1996-2007, 1996-2008, 1996-2009 and 1996-2012.

In Figure 2 you can see the shape of dynamic correlation curves. Each graph of Figure 2 displays the dynamic correlation value ( $y$-label) in dependence on the frequency ( $x$-label). The range of business cycle frequency is emphasized using horizontal lines. Since Figure 2 is illustrative and the eye-metric evaluation of the graphs in Figure 2 is quite difficult, we add a numerical evaluation of variability of dynamic correlation (Table 1). Table 1 also contains the values of dynamic correlation in full range of frequencies and in business cycle frequencies calculated according to the Formula (2). Focusing on the results of dynamic correlation presented in Table 1 (in business cycle as well in full range of frequencies) we can generally see a fluctuation among the values. The correlation between the euro area and Germany, which is economically the most important member of the euro area, stay quite stable across the four data samples. The variability of dynamic 
correlation between the euro area and Germany in 1996-2007 is the lowest among all of the data samples and has the tendency to grow with respect to the growing sample size, after macroeconomic shocks appear. In the period 1996-2008 the level of co-movement is the lowest in most cases. Obviously, the symmetric shock caused by the financial crisis was fully transmitted after the year 2008 .

Figure 2

Dynamic Correlation Curves between EA12, Germany and V4 Countries

EA 12

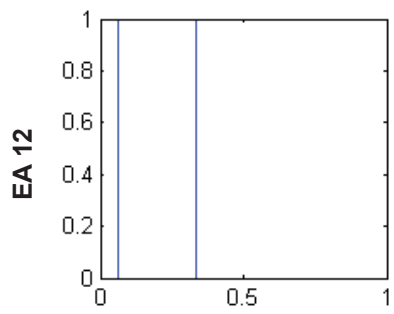

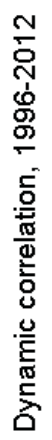

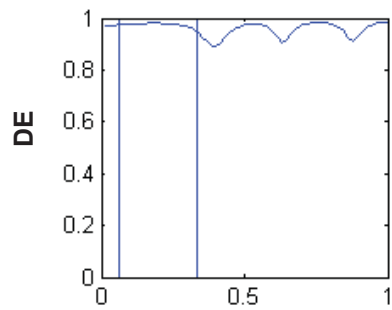

HU
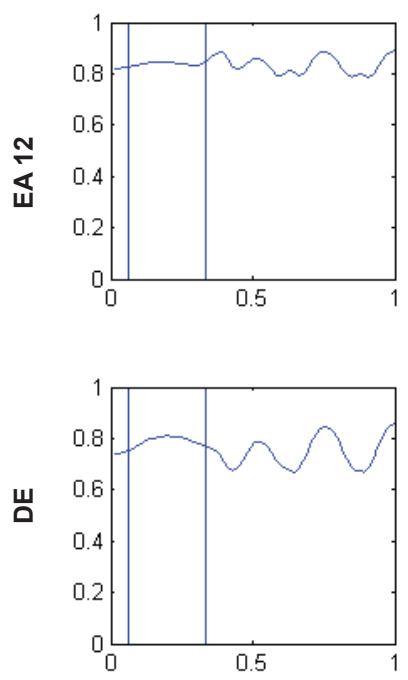

DE
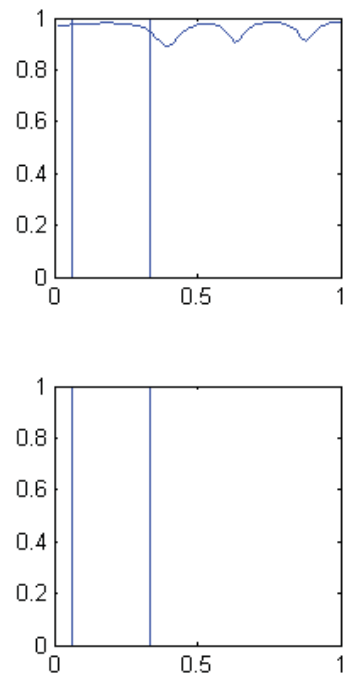

PL
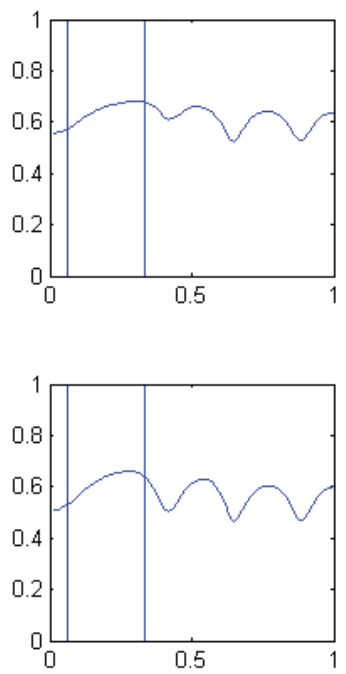

CZ
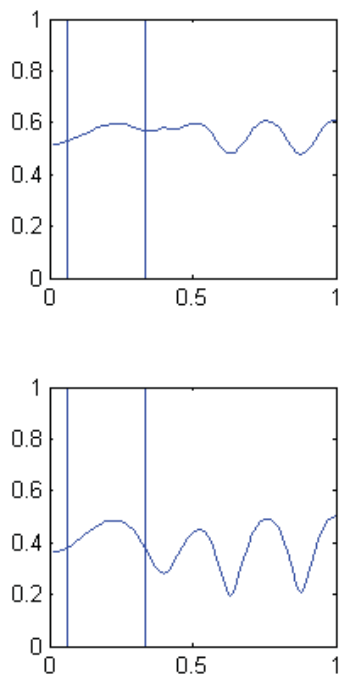

SK
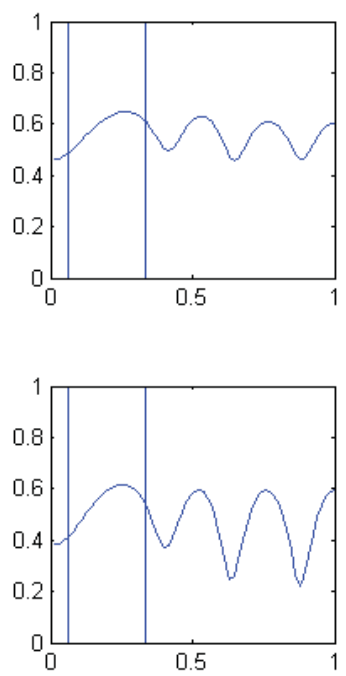
Figure 2 - continuation
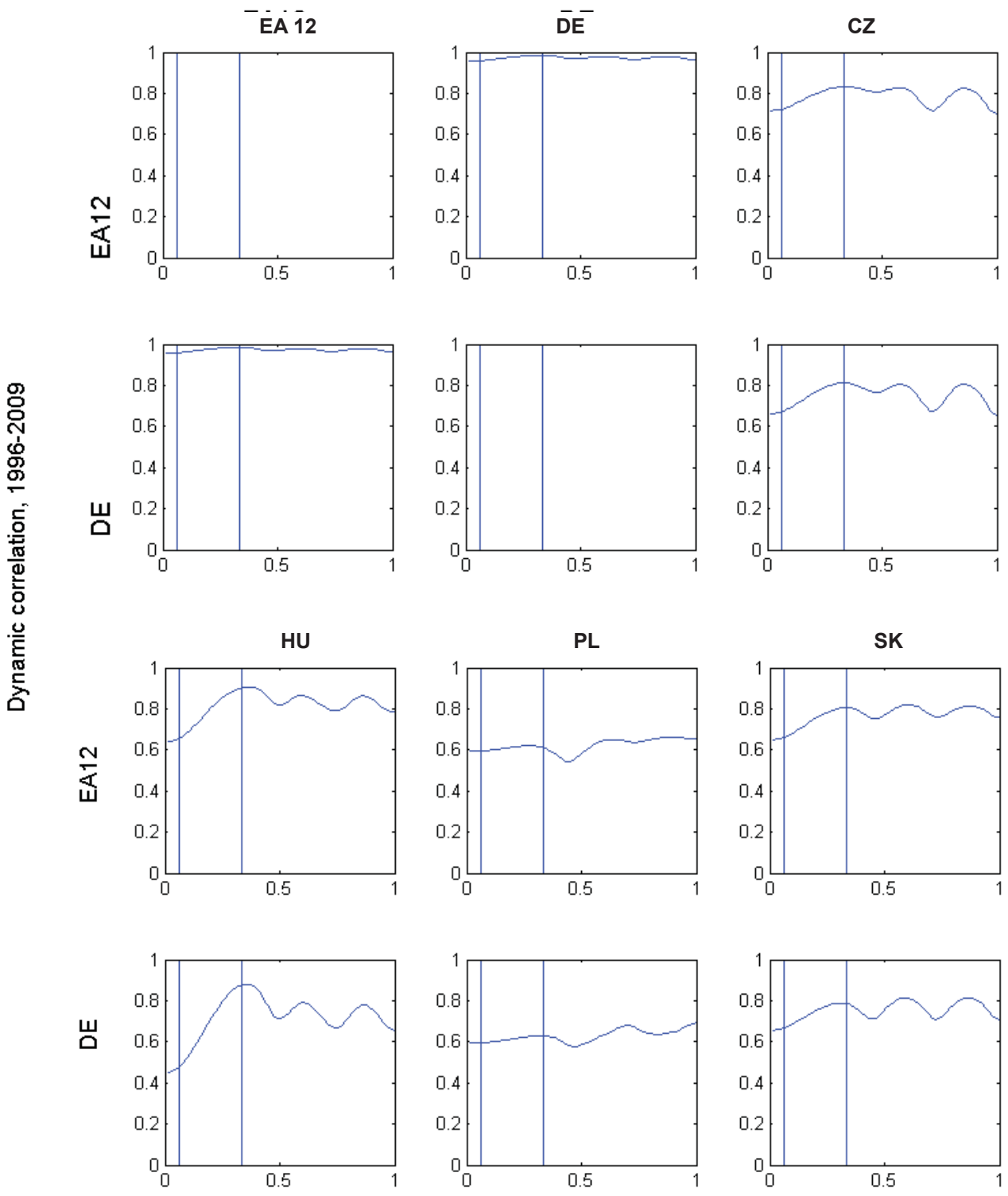
Figure 2 - continuation
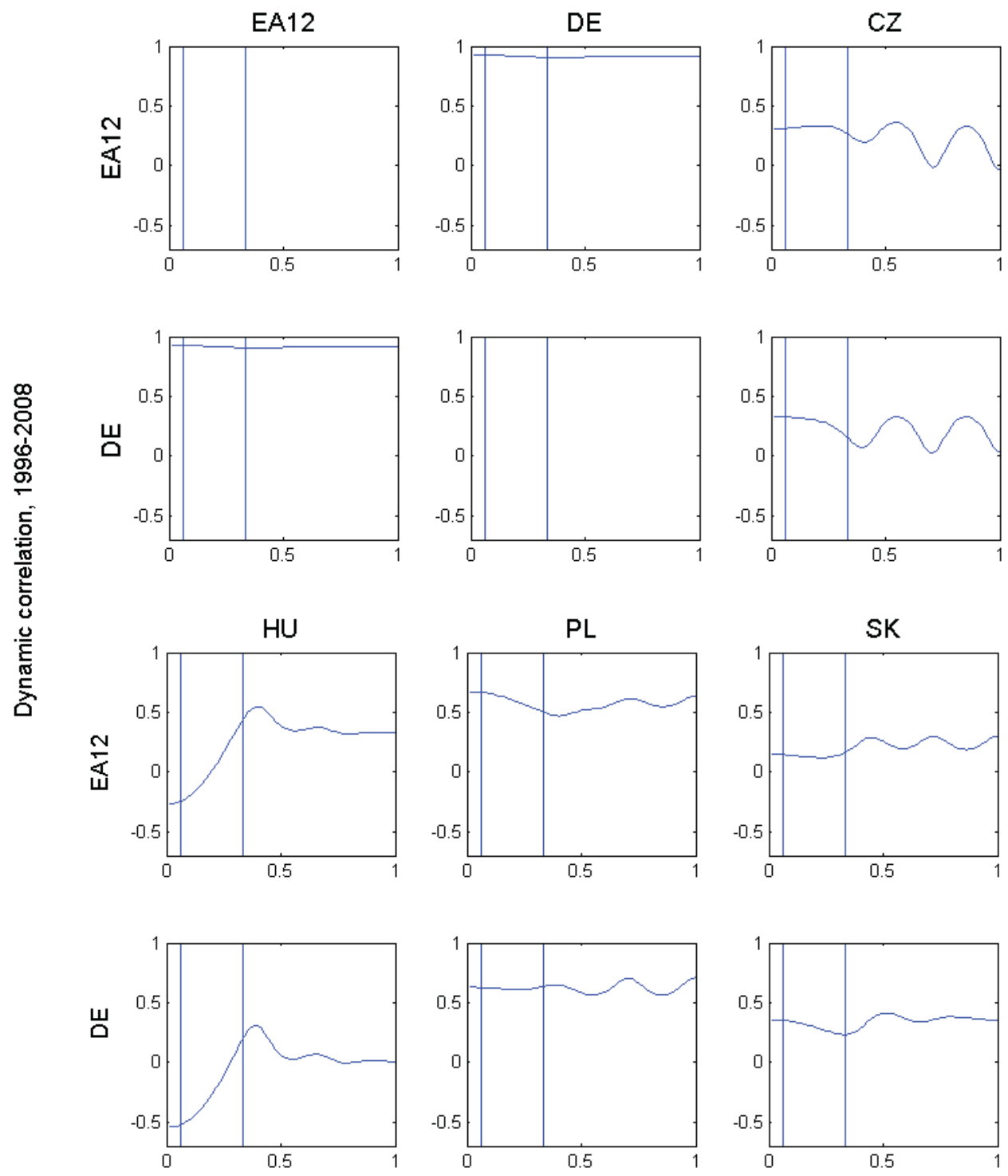
Figure 2 - continuation
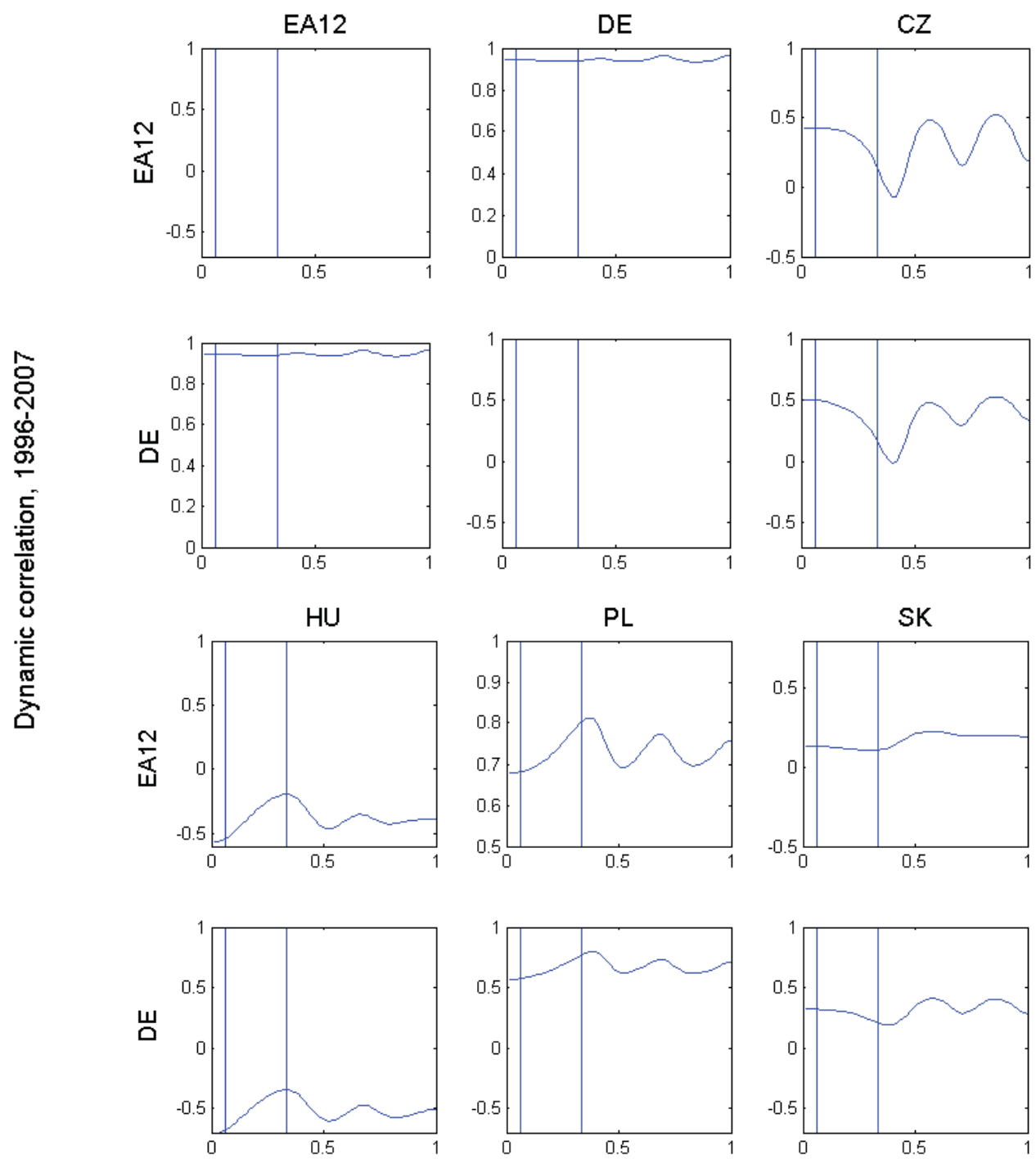

Note: dynamic correlation value ( $y$-label), frequency ( $x$-label)

The measured values for the Czech Republic in business cycle frequencies fluctuate within a growing sample, which shows the highest level of co-movement in the period 1996-2009. However, the variability of dynamic correlation in business cycle frequencies increases in relation to the euro area, whereas decreases in relation to Germany. These two neighbouring countries are an example of specialization which crosses the borders. In the context of the OCA theory, the level of the real convergence is different despite the high business cycle correlation of both samples. 
Table 1

Dynamic Correlation and Its Variability between EA12, Germany and Selected Countries

\begin{tabular}{|c|c|c|c|c|c|c|c|c|}
\hline & \multicolumn{2}{|c|}{ 1996-2012 } & \multicolumn{2}{|c|}{ 1996-2009 } & \multicolumn{2}{|c|}{ 1996-2008 } & \multicolumn{2}{|c|}{ 1996-2007 } \\
\hline & EA12 & DE & EA12 & DE & EA12 & DE & EA12 & DE \\
\hline & \multicolumn{8}{|c|}{ Dynamic correlation in business cycle frequencies } \\
\hline EA12 & 1 & 0.9771 & 1 & 0.9724 & 1 & 0.9184 & 1 & 0.9413 \\
\hline DE & 0.9771 & 1 & 0.9724 & 1 & 0.9184 & 1 & 0.9413 & 1 \\
\hline CZ & 0.5698 & 0.4446 & 0.7787 & 0.7423 & 0.3221 & 0.2967 & 0.3874 & 0.4318 \\
\hline HU & 0.8335 & 0.7869 & 0.7748 & 0.6689 & -0.0282 & -0.3102 & -0.3517 & -0.4922 \\
\hline PL & 0.6409 & 0.6142 & 0.6072 & 0.6093 & 0.6138 & 0.6177 & 0.7143 & 0.6341 \\
\hline \multirow[t]{2}{*}{ SK } & 0.5885 & 0.5440 & 0.7352 & 0.7334 & 0.1329 & 0.3083 & 0.1206 & 0.2917 \\
\hline & \multicolumn{8}{|c|}{ Dynamic correlation in full range of frequencies } \\
\hline EA12 & 1 & 0.9744 & 1 & 0.9695 & 1 & 0.9183 & 1 & 0.9426 \\
\hline DE & 0.9744 & 1 & 0.9695 & 1 & 0.9183 & 1 & 0.9426 & 1 \\
\hline$C Z$ & 0.5569 & 0.4198 & 0.7686 & 0.7286 & 0.3102 & 0.2951 & 0.3853 & 0.4378 \\
\hline HU & 0.8269 & 0.7695 & 0.7563 & 0.6367 & -0.0265 & -0.3163 & -0.3838 & -0.5210 \\
\hline PL & 0.6244 & 0.5912 & 0.6034 & 0.6065 & 0.6186 & 0.6204 & 0.7075 & 0.6242 \\
\hline \multirow[t]{2}{*}{ SK } & 0.5608 & 0.5060 & 0.7243 & 0.7211 & 0.1476 & 0.3231 & 0.1290 & 0.2954 \\
\hline & \multicolumn{8}{|c|}{ Variability of dynamic correlation in business cycle frequencies } \\
\hline EA12 & 0 & 0.00011 & 0 & 0.00007 & 0 & 0.00004 & 0 & 0.00001 \\
\hline DE & 0.00011 & 0 & 0.00007 & 0 & 0.00004 & 0 & 0,00001 & 0 \\
\hline CZ & 0.00028 & 0.00118 & 0.00110 & 0.00189 & 0.00042 & 0.00309 & 0.00864 & 0.01099 \\
\hline HU & 0.00002 & 0.00022 & 0.00564 & 0.01514 & 0.04804 & 0.05381 & 0.01081 & 0.00994 \\
\hline PL & 0.00076 & 0.00103 & 0.00005 & 0.00014 & 0.00280 & 0.00005 & 0.00155 & 0.00368 \\
\hline \multirow[t]{2}{*}{ SK } & 0.00166 & 0.00252 & 0.00191 & 0.00134 & 0.00018 & 0.00153 & 0.00008 & 0.00130 \\
\hline & \multicolumn{8}{|c|}{ Variability of dynamic correlation in full range of frequencies } \\
\hline EA12 & 0 & 0.00062 & 0 & 0.00006 & 0 & 0.00004 & 0 & 0.00007 \\
\hline DE & 0.00062 & 0 & 0.00006 & 0 & 0.00004 & 0 & 0.00007 & 0 \\
\hline$C Z$ & 0.00142 & 0.00701 & 0.00169 & 0.00251 & 0.01235 & 0.01012 & 0.02459 & 0.02110 \\
\hline HU & 0.00079 & 0.00278 & 0.00467 & 0.01156 & 0.05321 & 0.05165 & 0.00857 & 0.00815 \\
\hline PL & 0.00189 & 0.00300 & 0.00105 & 0.00093 & 0.00328 & 0.00150 & 0.00144 & 0.00372 \\
\hline SK & 0.00343 & 0.01188 & 0.00204 & 0.00193 & 0.00348 & 0.00239 & 0.00180 & 0.00387 \\
\hline
\end{tabular}

Source: own calculation

Hungary has an increasing level of co-movement measured in business cycle frequencies spanning from negative (1996-2007) through zero-level (1996-2008) to the positive value (1996-2009, 1996-2012). The level of co-movement after the crisis in 1996-2009 
and 1996-2012 becomes quite similar. The volatility arises dramatically in 1996-2008. Turning our attention to the full range of frequencies we can see the same fluctuation as in case of business cycle frequencies. Both the lowest and the highest level of co-movement are achieved in the same period of 1996-2008 and 1996-2012, respectively. In comparison with the Czech Republic, the variability of dynamic correlation in Hungary decreases after the symmetric shock appears.

The co-movement measures for Poland show a larger volatility of results with respect to the euro area and Germany and to both frequency ranges. In the business cycle frequencies the highest value of dynamic correlation is in the period 1996-2007 and the lowest value in 1996-2009. Note that this situation is opposite to the case of Slovakia. The volatility of dynamic correlation slightly arises in 1996-2008, during the crisis. In full range of frequencies the highest value of dynamic correlation is achieved also in the period 1996-2007, but the lowest level for co-movement with Germany is in the period 1996-2012 and with the euro area in the period 1996-2009.

For the last case - Slovakia - the co-movement has the same tendency (and even very close results) in business cycle frequency as in the full range of frequency. The highest values of co-movement is achieved in 1996-2009 (after the crisis) with a lower variability followed by a decrease of dynamic correlation level in the period 1996-2012 and an increase of its volatility. The lowest level of dynamic correlation can be seen in the first periods of 1996-2007.

Generally, we can identify the highest co-movement in the business cycle frequency range during the period 1996-2009 for the Czech Republic and Slovakia, and in the period 1996-2007 for Poland. In the full range of frequencies the results remain the same for the Czech Republic, Hungary and Slovakia. We can also point out to a big difference between the highest and the lowest level of co-movement for Slovakia and Hungary, also for the Czech Republic, which is, however, a bit smaller. As for Poland, the difference is not so remarkable. The increase in variability of dynamic correlation in business cycle frequencies was found only in the case of co-movement between Germany and the Czech Republic.

To identify a specialization in production we use indexes based on the gross value added and the figure of employed population in a selected region/country and sector. We employ the Herfindahl-Hirschman Index for specialization, the Krugman Dissimilarity Index and the Lilien Index (Table 2). Our results correspond to the results of economic cycle correlation in time and frequency domains in the previous chapter, as well as to our assumption of sector-specific shocks. Even though the results could be biased, since we base our calculation on the whole European Union (EU27), all of the indicators identify the highest degree of specialization in the case of the Czech Republic. The Krugman Dissimilarity Index and the Lilien Index show a substantial increase after the year 2008 when the negative symmetric shock caused by the financial crisis appears. 
Table 2

Industrial Specialization

\begin{tabular}{|c|c|c|c|c|c|}
\hline Periods & DE & CZ & HU & PL & SK \\
\hline \multicolumn{7}{|c|}{ Herfindahl-Hirschman Index } \\
\hline $2000-2012$ & 0.1971 & 0.2585 & 0.2093 & 0.2022 & 0.2334 \\
\hline $2000-2009$ & 0.1988 & 0.2468 & 0.2071 & 0.1970 & 0.2166 \\
\hline $2000-2008$ & 0.2009 & 0.2441 & 0.2088 & 0.1952 & 0.2172 \\
\hline $2000-2007$ & 0.2006 & 0.2380 & 0.2081 & 0.1932 & 0.2141 \\
\hline \multicolumn{7}{|c|}{ Krugman Dissimilarity Index } \\
\hline $2000-2012$ & 0.2130 & 0.3832 & 0.2632 & 0.3205 & 0.3763 \\
\hline $2000-2009$ & 0.2188 & 0.3521 & 0.2437 & 0.2954 & 0.3261 \\
\hline $2000-2008$ & 0.2233 & 0.3388 & 0.2400 & 0.2825 & 0.3209 \\
\hline $2000-2007$ & 0.2217 & 0.3227 & 0.2334 & 0.2767 & 0.3048 \\
\hline \multicolumn{7}{|c|}{ Lilien Index } \\
\hline $2000-2012$ & 0.0023 & 0.0047 & 0.0059 & 0.0087 & 0.0090 \\
\hline $2000-2009$ & 0.0024 & 0.0045 & 0.0053 & 0.0091 & 0.0094 \\
\hline $2000-2008$ & 0.0023 & 0.0039 & 0.0053 & 0.0090 & 0.0091 \\
\hline $2000-2007$ & 0.0023 & 0.0041 & 0.0053 & 0.0088 & 0.0092 \\
\hline
\end{tabular}

Source: own calculation

\section{Robustness Analysis}

Finally, we estimate the Concordance Index to verify our previous results of business cycles synchronization during the financial crisis. Table 3 compares the Concordance Index and the Correlation Coefficient in time domain.

As for the Czech Republic, the Concordance Index of economic activity co-movements is volatile among the samples and values for the euro area and Germany, but there are no strong differences. The highest co-movement is achieved for the sample in the period 1996-2009, the lowest for 1996-2007 (this results is not confirmed by the dynamic correlation). Note that the tendency of the Concordance Index is growing from 1996-2007 to 1996-2009. In case of Hungary the Concordance Index has a growing tendency through all samples, i.e. the smallest value for 1996-2007 (this result is not confirmed by the dynamic correlation), growing values in 1996-2008 and 1996-2009, with the highest value in 1996-2012. The biggest disproportion appears in Poland, where the index is the highest for the sample in the period 1996-2012, the lowest in co-movement with the euro area in the period 1996-2008 and in co-movement with Germany in 1996-2007. Note that the Correlation Coefficient and the dynamic correlation reach the highest level of co-movement in the period 1996-2007. 
The results for Slovakia are volatile among the samples and the values for the euro area and Germany, but there are no strong differences. Like in the case of Poland, the Concordance Index indicates a disproportion of the results. The highest co-movement measured by the Concordance Index is in the period 1996-2008, the lowest in co-movement with the euro area in the period 1996-2007 and in co-movement with Germany in 1996-2012.

Table 3

Concordance Index and Correlation Coefficient

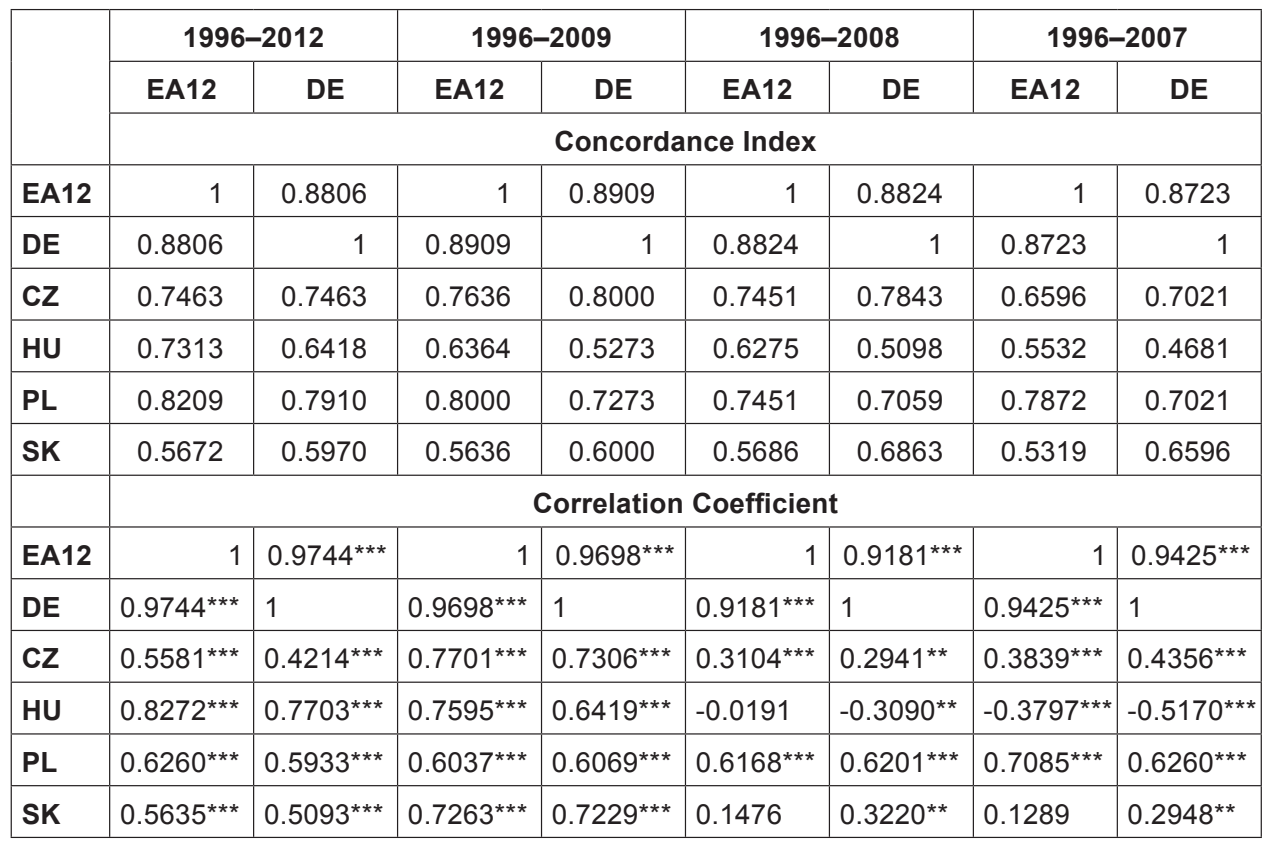

Source: own calculation

In order to complete the calculations we present also the classical correlation coefficients results in Table 3. As mentioned above in the methodology commenting the Formula (2), the classical correlation is equal to the dynamic correlation with the integration limits $\omega_{1}=0, \omega_{2}=\pi$. A more detailed look to Tables 1 and 3 shows only negligible differences between the classical correlation and the full-range dynamic correlation results, thus the comments from Section 5 would be valid for both cases. Comparing the results of the classical Correlation Coefficient and the Concordance Index we find some discrepancy causing an inappropriate interpretation of co-movement via these two basic instruments.

\section{Discussion}

Kočenda (2001) or Kutan and Yigit (2005) discovered that the real convergence of the new EU member countries is rather idiosyncratic although there is empirical evidence 
showing that it will take several decades for the convergence to be fully completed (Kočenda et al., 2006). These integration tendencies are given by intra-industry trade (Fidrmuc, 2004). Artis et al. (2008) confirmed that extensive trade and financial linkage result in further increases in the business cycle correlation, but an increase in the labour market regulation and pursuing national fiscal policies may bring a counteracting effect. Kučerová (2009) confirms the existence of strong relation between trade and financial integration in new EU member countries (except for Bulgaria and Romania). According to this, the growing foreign trade of these countries contributes to an increase in the level of foreign assets and liabilities and vice versa.

These effects, especially a sectoral specialization, play an important role in the monetary policy implementation. Various degrees of price adjustments can be temporarily influenced by different sizes of sectors with strong or weak price dynamics. Peersman and Smets (2002) and ECB (2004) assumed that the capital intensity, the average firm size and the degree of openness to foreign competition are important factors which determine monetary policy impact on output growth and inflation. More specifically, the sectors with higher capital intensity, a lower average firm size and lower degrees of openness are more sensitive to the monetary policy changes than other sectors within the country.

Concurrently, sector-specific responses are not only exposed to different kinds of exogenous shocks but also to symmetric shocks. Therefore, cross-country differences play an important role in discussions about the economic cycle synchronization. It is generally agreed that increased intra-industry trade can lead to a higher synchronization of economic cycles within the currency union; nevertheless, Imbs (2001a, 2001b) showed that sectoral specialization has a negative impact on the business cycle synchronization even if it can be the result of trade and financial integration. The reason is the fact that sectoral specialization can lead to an increasing importance of sector-specific shocks and finally reduce synchronization of economic cycle. Afterwards, Imbs (2003) provides empirical evidence that a direct positive impact of intra-industry trade on economic cycle synchronization usually dominates the negative effect of sectoral specialization.

\section{Conclusion}

We have found a rapid increase in business cycle correlation at business cycle and full range of frequencies after the year 2008, when the symmetric shock caused by the financial crisis appears. In comparison with the Concordance Index we did not find significant differences. However, the results show an increase in the variability of dynamic correlation between the Czech Republic and the euro area. On the other hand, the variability of dynamic correlation decreases in relation to Germany. The HerfindahlHirschman Index for Specialization, the Krugman Dissimilarity Index and the Lilien Index confirmed the highest degree of sectoral specialization in case of the Czech Republic.

We discussed the business cycle correlation and its robustness in the context of the OCA 
theory. We conclude that the dynamic correlation provides a more detailed look to the structure of time series co-movement. We suppose that macroeconomic shocks have asymmetric effects which differ by the frequency of adjustment across the sectors. Our contribution lies in the identification of these asymmetric shocks covered in the business cycle correlation in time domain.

\section{References}

Artis, M. J., Fidrmuc, F., Scharler, J. (2008), "The Transmission of Business Cycles: Implications for EMU Enlargement." The Economics of Transition, The European Bank for Reconstruction and Development, Vol. 16, No. 3, pp. 559-582.

Artis, M. J., Zhang, W. (1999), "Further Evidence on the International Business Cycle and the ERM: Is There a European Business Cycle?" Oxford Economic Papers, Vol. 51, No. 1, pp. 120-32.

Bátorová, I., Fidrmuc, J., Korhonen, I. (2013), "China in the World Economy: Dynamic Correlation Analysis of Business Cycles." CESifo Economic Studies, forthcoming.

Bertola, G. (1993), "Factor Shares and Savings in Endogenous Growth." American Economic Review, Vol. 83, No. 5, pp. 1184-98.

Bry, G., Boschan, C. (1971), "Cyclical Analysis of Time Series: Selected Procedures and Computer Programs," Technical Paper 20, National Bureau of Economic Research, New York.

Carlsson, M., Nordstrom Skans, O. (2012), "Evaluating Microfoundations for Aggregate Price Rigidities: Evidence from Matched Firm-Level Data on Product Prices and Unit Labor Cost." American Economic Review, Vol. 102, No. 4, pp. 1571-95.

Croux, C., Forni, M., Reichlin, L. (2001), "A Measure of Co-movement for Economic Variables: Theory and Empirics." The Review of Economics and Statistics, Vol. 83, No. 2, pp. 232-241.

Druant, M., Fabiani, S., Kezdi, G., Lamo, A., Martins, F., Sabbatini, R. (2009), "How Are Firms' Wages and Prices Linked: Survey Evidence in Europe." National Bank of Belgium, Working Paper Research No. 174.

ECB (2004), "Sectoral Specialisation in the EU a Macroeconomic Perspective." Occasional Paper Series of the European Central Bank, July, No. 19.

Eichengreen, B. (1992), "Should the Maastricht Treaty Be Saved?" Department of Economics, Princeton University, Princeton Studies in International Finance, International Economics Section, No. 74 .

Eurostat (2012a), "National Accounts." [on-line, cit. 2012-10-20] Available at http://epp.eurostat. ec.europa.eu/portal/page/portal/national_accounts/data/database.

Eurostat (2012b), "Labour Market Statistics." [on-line, cit. 2012-07-05] Available at http://epp.eurostat. ec.europa.eu/portal/page/portal/labour_market/job_vacancies/database.

Fatás, A. (1997), "EMU: Countries or Regions? Lessons from the EMS Experience." European Economic Review, Vol. 41, No. 3-5, pp. 743-751.

Fidrmuc, J. (2004), "The Endogeneity of the Optimum Currency Area Criteria, Intraindustry Trade, and EMU Enlargement." Contemporary Economic Policy, Vol. 22, No. 1, pp. 1-12.

Fidrmuc, J., Ikeda, T., Iwatsubo, K. (2012), "International Transmission of Business Cycles: Evidence from Dynamic Correlations." Economics Letters, Vol. 114, No. 3, p. 252-255.

Fidrmuc, J., Korhonen, I. (2006), "Meta-Analysis of the Business Cycle Correlation between the Euro Area and the CEECs." Journal of Comparative Economics, Vol. 34, No. 3, pp. 518-537.

Fidrmuc, J., Korhonen, I. (2010), "The Impact of the Global Financial Crisis on Business Cycle in Asian Emerging Economies." Journal of Asian Economics, Vol. 21, pp. 293-303.

Harding, D., Pagan, A. (2006), "Synchronization of Cycles." Journal of Econometrics, Vol. 132, No. 1, pp. 59-79. 
Herfindahl, O. C. (1950), "Concentration in the Steel Industry." Ph. D. thesis, Columbia University.

Hirschman, A. O. (1964), "The Paternity of an Index." The American Economic Review, Vol. 54, pp. 761-762.

Hodrick, R. J., Prescott, E. C. (1980), "Post-War U.S. Business Cycles: An Empirical Investigation." Mimeo, Carnegie-Mellon University, Pittsburgh.

Horváth, R., Komárek, L. (2002), "Teorie optimálních měnových zón: rámec k diskusím o měnové integraci." Finance a úvěr, Vol. 52, No. 7-8, pp. 386-407.

lacobucci, A., Noullez, A. (2005), "A Frequency Selective Filter for Short-Length Time Series." Computational Economics, Vol. 25, pp. 75-102.

Imbs, J. (2001a), "Co-fluctuations." Centre for Economic Policy Research Discussion Paper, No. 2267.

Imbs, J. (2001b), "Sectors and the OECD Business Cycle." Centre for Economic Policy Research Discussion Paper, No. 2473.

Imbs, J. (2003), "Trade, Finance, Specialisation and Synchronization." Centre for Economic Policy Research Discussion Paper, No. 3779.

Kočenda, E. (2001), "Macroeconomic Convergence in Transition Economies." Journal of Comparative Economics, Vol. 29, No. 1, pp. 1-23.

Kočenda, E., Kutan, A. M., Yigit, T. M. (2006), "Pilgrims to the Eurozone: How Far, how Fast?" Economic Systems, Vol. 30, No. 4, pp. 311-327.

Krugman, P. R. (1991), "Increasing Returns and Economic Geography." Journal of Political Economy, Vol. 99, No. 3, pp. 484-499.

Krugman, P. R. (1992), Geography and Trade. Cambridge, Massachusetts: The MIT Press.

Krugman, P. R. (1993), "Lessons of Massachusetts for EMU," in Torres, F., Giavazzi, F., ed., Adjustment and Growth in the European Monetary Union, Cambridge: Cambridge University Press, pp. 241-60.

Kučerová, Z. (2009), "Measuring Financial Integration in Central Europe through International Investment Positions." Eastern European Economics, Vol. 47, No. 4, pp. $25-41$.

Kutan, A. M., Yigit, T. (2005), "Nominal and Real Stochastic Convergence: Are the New EU Members Ready to Join the Eurozone?" Journal of Comparative Economics, Vol. 33, No. 2, pp. 387-400.

Lilien, D. M. (1982), "Sectoral Shifts and Cyclical Unemployment." Journal of Political Economy, Vol. 90, No. 4, pp. 777-793.

Lucas, R. (1976), "Econometric Policy Evaluation: A Critique," in Brunner, K., Meltzer, A., ed., The Phillips Curve and Labor Markets. Carnegie-Rochester Conference Series on Public Policy, pp. 19-46.

Messina, J., Strozzi, Ch., Turunen, J. (2009), "Real Wages over the Business Cycle OECD Evidence from the Time and Frequency Domains." European Central Bank Working Paper No. 1003.

Mundell, R. A. (1961), "A Theory of Optimum Currency Areas." The American Economic Review, Vol. 51, No. 4, pp. 509-517.

Peersman, G., Smets, F. (2002), "The Industry Effects of Monetary Policy in the Euro Area." European Central Bank Working Paper No. 165.

Rauch, J., Weinhold, D. (1999), "Openness, Specialization, and Productivity Growth in Less Developed Countries." Canadian Journal of Economics, Vol. 32, No. 4, pp. 1009-1027. 